\title{
Citrus Essential Oils a Good Alternatives to Antibiotics in Aquaculture
}

\author{
Monique Mancuso* \\ Department of Biological Resources and Marine Biotechnology IRBIM-CNR, Italy.
}

*Corresponding author: Monique Mancuso, Department of Biological Resources and Marine Biotechnology IRBIM-CNR, Italy.

Received Date: December 21, 2018

Published Date: January 08, 2019

\section{Opinion}

Aquaculture is the farming of aquatic organisms, including fish, molluscs, crustaceans and aquatic plants [1]. Aquaculture is a booming sector because of the always increasing demand which is partly opposed by the insurgency of infectious diseases affecting the farm animals and that are a major risk and responsible for substantial economic losses in this sector [2-5]. The unprejudiced use of antibiotics to prevent or to treat the bacterial diseases can lead to the development bacterial resistant strains that could be threat to human health [6-8]. Several measures have been taken on national and international scales to reduce or even halt the use of antibiotics in aquaculture. In this context research is being carried out on new natural products that have an antibiotic capacity such as natural essential oils [8,9] Essential oils (EOs) are aromatic oily liquids characterized by a strong odour and produced by fruits or plants. As the majority of EOs their chemical constituents give a good resistance to pathogens [10]. EOs are used in many industrial sectors such as food field up to perfumery and pharmaceuticals $[11,12]$ studied the effects of Citrus sinensis against Streptococcus iniae [13]; showed that Citrus lemon essential oil significantly inhibited the growth of Yersinia ruckeri, Aeromonas hydrophila, Listonella anguillarum and Citrobacter freundii.

Mancuso et al. (in press) showed V. anguillarum and Photobacterium damselae. subsp piscicida showed high sensitivity to Citrus Eos. Finally [14] highlighted the importance one of the major citrus components the limonene against spoilage microorganisms. In my opinion I think that only a mix of components give a good action against bacterial growth so other studies are necessary to better understand the inhibitory action of citrus essential oils [15].

\section{Acknowledgment}

None.

\section{Conflicts of Interest}

No conflicts of interest.

\section{References}

1. FAO (2006) The State of World Fisheries and Aquaculture (SOPHIA) P: 5.

2. Mancuso M (2013a) Aquaculture advancement. J Aquac Res Development 5: e108.

3. Mancuso M (2013b) Fish welfare in aquaculture. Journal of Aquaculture Research \& Development 4(6): 1.

4. Subasinghe R (2009) Disease control in aquaculture and the responsible use of veterinary drugs and vaccines: the issues, prospects and challenges in Rogers $\mathrm{C}$ and Basurco B (eds.) The use of veterinary drugs and vaccines in Mediterranean aquaculture.

5. Mancuso M, Macri B, Monaco S, Zaccone R, Paradiso ML, et al. (2005) Microbiological and anatomo-hystopathological aspects during an outbreak of flavobacteriosis in farmed common dentex (Dentex dentex) Ittiopatologia 2(1): 15-20.

6. Mancuso M (2015a) Essential Oils: The New Frontier to Pro-long the Shelf Life of Fish Products. Int J Marine Sci Ocean Technol 2: 1-2.

7. Mancuso M (2015b) Effects of fish farming on marine environment. J of Fisheries Sciences com 9(3): 88-89.

8. Mancuso M (2015c) Fish Mycobacteriosis: an emerging disease in Italy. Fisheries and Aquaculture Journal.

9. Manuguerra S, Caccamo L, Mancuso M, Arena R, Rappazzo AC, et al. (2018) The antioxidant power of horseradish, Armoracia rusticana, underlies antimicrobial and antiradical effects, exerted in vitro. Natural product research: 1-4.

10. Mancuso M (2018) The antiomicrobial effect of Wasabia japonica and Armoracia rusticana. J of marine biology and aquascape (1): 1 .

11. Palazzolo E, Laudicina VA, Germanà MA (2013) "Current and Potential Use of Citrus Essential Oils" Current Organic Chemistry 17: 3042-3049.

12. Acar U, Kesbic OS, Ylmaz S, Nejdet Gültepe, Ali Türker (2014) Evaluation of the effects of essential oil extracted from sweet orange peel (Citrus sinensis) on growth rate of tilapia (Oreochromis mossambicus) and possible disease resistance against Streptococcus iniae. Aquaculture 437: 282-286. 
13. Öntaş C, Baba E, Kaplaner E, Küçükaydin S, Öztürk M, et al. (2016) Antibacterial activity of Citrus lemon Peel Essential Oil and Argania spinosa oil against fish pathogenic bacteria. Kafkas Univ Vet Fak Derg 22 (5): 741-749.

14. Giarratana F, Muscolino D, Beninati C, Ziino G, Giuffrida A, et al. (2016) Activity of $\mathrm{R}(+)$ limonene on the maximum growth rate of fish spoilage organisms and related effects on shelf-life prolongation of fresh gilthead sea bream fillets International. Journal of Food Microbiology 237: 109113.

15. Mancuso M (2014) Emerging bacterial diseases in Mediterranean Mariculture J of acquacultre and research 1: 2. 